\title{
Stewardship and Corporate Governance in the Banking Sector: Evidence from Nigeria
}

\author{
Jafaru Jimoh (PhD, FCA) \\ Department of Accounting, Auchi Polytechnic, Auchi, Nigeria \\ Tel: 234-80-3356-7995Ｅ-mail: chiefjjimohjafaru@yahoo.com \\ F.O Iyoha ( $\mathrm{PhD}, \mathrm{FCA})$ (Corresponding author) \\ Department of Accounting, Covenant University, Ota, Nigeria \\ Tel: 234-80-3351-5869 E-mail: iyohafrancis@yahoo.co.uk
}

Received: March 19, 2012

Accepted: April 7, 2012

Published: May 15, 2012

doi:10.5430/afr.v1n1p198

URL: http://dx.doi.org/10.5430/afr.v1n1p198

\begin{abstract}
A healthy corporate governance culture is imperative in the banking sector where the retention of public confidence remains of utmost importance. In this regard, the board of directors are the essential fulcrum upon which the mechanisms of corporate governance and management rest. In Nigeria, however, poor corporate governance has been identified as one of the major factors in virtually all known instances of distress in banks. This is taking place against the backdrop of the existence of Code of Corporate Governance for organizations (including banks) in Nigeria. This contradiction is evaluated in this study which seeks to identify the challenges of corporate governance faced by directors in the Nigerian banking sector. Using the ex-post facto research design, this study draws on the views of executive and non-executive directors of banks in Nigeria, applying simple percentages, averages and rank order as statistical tools for the analysis of data. The study reveals the major challenges of corporate governance as the ineffectiveness of audit committees and lack of shareholder activism. The study recommends, amongst others that, shareholder activism should be legally required and encouraged and the level of such activism should be reported upon by the chairman in his statement and the auditors in their report. Similarly, audit committee should be responsible for hiring, firing and recommending the fees for non-executive directors and external auditors.
\end{abstract}

Keywords: Corporate governance, Board of Director, Banks, Stakeholders, Stewardship

\section{Introduction}

The management and administration of the activities of corporate bodies occupy a central place in the development of the economy of any nation. This is particularly important for banking institutions where the retention of public confidence through the enthronement of good corporate governance remains of utmost importance. Thus, given the role of the banking industry in the mobilization of funds, the allocation of credit to the needy sectors of the economy, the payment and settlement system and the implementation of monetary policy, the issue of good corporate governance cannot be too strongly emphasized.

In the past two decades, however, there have been concerns among investors and regulators in Nigeria that banks are performing poorly and some failing due mainly to weak corporate governance structure. It is to address this concern among others, that the Central Bank of Nigeria (CBN) issued a Code of Conduct for Directors of licensed Banks and Financial Institutions 2006. This is besides the Code of Corporate Governance earlier issued in 2003, the provisions of which banks were expected to comply with. Some of the provisions of these codes reflect world best practices. For instance, the codes among others provide for the separation of the roles of the Chief Executive Officer (CEO) and the board chairman and prescribed for the position of non-executive and executive directors on the board. Compliance with the provisions of these codes is compulsory.

The prescription of non-executive directors on the boards of banks is particularly instructive as it is in consonance with agency theory which suggests that non-executive directors act as a check and balance mechanism. In-spite of these provisions, the corporate governance culture in Nigeria has consistently failed to be responsible to the stakeholders, 
accountable to the shareholders and has no deep-rooted mechanism to maintain a balance among the major players (board of directors, shareholders, and management) in corporate governance (Quadri, 2010).

The questions that beg for answer following these initiatives are (i) what weaknesses have impaired directors' successes in the corporate governance environment in the banking sector in Nigeria? (ii) what corporate governance challenges do the directors face following the banking consolidation? and (iii) what principles and practices should directors embrace to enhance good corporate governance in the banking sector? From a banking sector perspective, these questions are pertinent because good corporate governance demands that directors of banks operate the activities of the banks in a safe and sound manner and comply with applicable laws and regulations in order to protect the interest of stakeholders. Interestingly, however, Wilson (2006), observed that not many Nigerian banks are noted for their "strict observance of corporate governance best practices and ethical standards in their operations."

Given the above background, the need to understand the factors/issues which militate against/enhance the performance of directors has become imperative and deserves serious attention in Nigeria. This study is therefore an attempt to bridge that gap by providing empirical evidence based on the perception of executive and non-executive directors of banks in the Nigeria banking sector for the informed awareness of relevant stakeholders.

The remaining part of this paper is organized as follows: the next section reviews recent literature on corporate governance, followed by the section which describes the research methods used in this study. Then followed by Section 4 which reports the results of the study, while section 5 is conclusion and recommendations.

\section{Literature Review}

Corporate governance mechanisms, as noted by Shleifer and Vishny's (1997:739), is "a set of mechanisms through which outside investors protect themselves towards getting a return on their investment." Corporate governance became significant in the $20^{\text {th }}$ century after the stock market crash in the US (1929). In the United States, the SEC has corporate governance mechanisms that govern the operations of the listed companies in that country.

In 2004, the United States Organizational Sentencing Guidelines (the "Guidelines") were amended to provide expanded guidance regarding the criteria for effective compliance programs of the SEC rules. The guidelines emphasize the importance of creating a "culture of compliance" within the organization; establish the governance and oversight responsibilities of the board and senior management; and frame the need for dedicating appropriate resources and authority. The Guidelines also focus on the relationship between governance, ethics, risk management, and compliance (Ball, 2004).

The impetus for good corporate governance practices began in the UK in the late 1980s and early 1990s when the British formed a number of committees to assess the financial aspects of corporate governance in the United Kingdom. The committees made far reaching recommendations most of which have been implemented. Though the idea of corporate governance developed in response to corporate failures, recent fraudulent events involving major companies around the world suggest that the idea has failed. The case of the collapse of Bank of Credit and Commerce International (BCCI), which according to Al-Faki, (2007) were due to 'incompetence, fraud, or abuse' is an example.

In Nigeria, the issue of corporate governance has been accorded serious attention by all sectors of the economy. For instance, the Securities and Exchange Commission (SEC) set up the Peterside Committee on corporate governance in public companies, the aim of which is to build credibility while ensuring transparency and accountability as well as maintaining an effective channel of information disclosure that would foster good corporate performance. The survey conducted by the Securities and Exchange Commission (SEC, 2003) in Nigeria showed that corporate governance is at an elementary stage, with only about $40 \%$ of quoted companies adopting it.

In the case of the banking sector, for instance, the breakdown of corporate governance practices became so serious that by 1996 the Central Bank of Nigeria (CBN) sacked 178 bank directors and blacklisted 75 others (NDIC, 1996:50). The details of the involvement of directors which culminated in the event is shown in Table 1

The effect of sharp practices on bank is a loss. The loss would result in depleted profit and depending on the size and strength of the bank, it could be forced to close down if the frequency and size of the frauds are high and persistent (Aikhorin, 1994). Thus, Nwankwo (1991), noted that fraud is the biggest single cause of bank failure in Nigeria. The criticisms following the banking failure, according to Okike (2004:705) became very pronounced and evoked a number of reactions including an increase in the number of agencies and legislative control measures many of which have implications for banking practice.

In considering accountability in corporate governance, Okechukwu (2007:17-23) citing Millstein (2001) identifies three elements of the U.S./U.K. system (which may apply in the Nigerian context) to provide some guidance on how boards 
may become accountable for corporate performance. These elements are independent oversight of board, contestability and participation by the board in strategy. Before the institution of the Code of Corporate Governance in Nigeria in 2003, a number of legislations (including the Companies and Allied Matters Act, CAMA, 1990) had influenced the operations of corporate enterprises. The enforcement and compliance of corporate governance in Nigeria is more of a self regulatory effort (devoid of ethical content) than statutory backing as obtains in the United kingdom and else where in the developed world.

The sliding ethical conduct in the Nigerian banking sector has been alluded to by a number of authors. For instance, Kolawole (as cited by Olajide, 2004), observes:

Promoting professionalism and ethics in the Nigerian banking industry faces a number of challenges as the milieu in which banking professionals are operating are bedeviled with misplaced values, greed and corruption with the result that these professionals see themselves as fighting a loosing battle to salvage a system apparently heading for the rock.

This situation has actually had adverse effects on the Nigerian banking system as captured by a number of other authors. Oloshore (1992) observes that the unethical climate in the Nigerian banking sector has been compounded by "some bank officials who have attracted a lot of notoriety to themselves through vain publicity and large scale frauds usually caused by immodest carriage." The involvement of staff other than directors in unethical practices following the breakdown of corporate governance is shown in Table 2 .

Soludo, (2004) also captured some of the unethical practices as "spate of frauds, ethical misconduct and falsification of returns by the banks to the Central bank", the unprofessional use of "female staff, some of whom have been reported to offer sex to win new customers" and banks which were not really banks at all, but "traders in foreign exchange, government treasury bills and direct importation of goods through phony companies." According to Soludo cited in Adedipe (2005) "there were a total of 1,036 reported cases of fraud in 2003 with a total loss in the sum of N9.3 billion." In 2004 and 2005 financial years, the total sum lost to fraud cases in the banks were $\$ 11$ billion and $\$ 12$ billion respectively. These amounts put together are no doubt, colossal when viewed against the background of the capitalization of some of the banks in 2003. The table below shows the number of fraud cases and staff involved between 1994 and 2007.

\section{Table 3 Fraud Cases Reported and Prosecuted}

The table below shows a summary of the fraud cases reported, prosecuted and the amount involved of all the cases discovered between 1996 and 2006.

In all of these incidents, the apex bank accused the operators of engaging in unethical practices and insider abuse, a situation it said resulted in erosion of the confidence and trust that capital market operation was built on. Though a number of cases have been prosecuted and many others are under investigation, only a small fraction has been convicted. It is not sufficient to charge persons of fraudulent behaviour but more efforts should be made to ensure that those charged are promptly tried. Any lapses will only send wrong signals that authorities are not serious about addressing the problems.

Even though the various governments have attempted to address the situation through the enactment of laws and regulations, the situation remains unabated. The laws have certainly become inadequate in addressing the trend. This suggests that it is an ethical issue. In order to achieve beneficial results the banks have to constantly ensure that ethical standards keep pace with changes in the banking sector.

\section{Research Methods}

The study adopted a quantitative research methodology using an ex post facto design. This design is useful in studies in which questions about people's past experiences are asked (Krishnaswami, 2003; Kibanja and Munene, 2009). The design was considered suitable for this study because respondents were asked questions about their past experiences as directors of listed banks. A sample of 122 respondents (68 non-executive and 54 executive directors) who had been on the board of banks between 2001 and 2008 (two years before the first code of corporate governance was issued and two years after the code of corporate governance for banks was issued) was purposively selected. Of the non-executive and executive directors, there were 12 and 15 females respectively.

The study employed both primary and secondary data. The primary data were obtained through the administration of a questionnaire. The information contained in the questionnaire was derived from the Code of Corporate Governance for Banks in Nigeria approved by the Central Bank of Nigeria. The secondary data were obtained from the records of the Nigeria Deposit Insurance Corporation (NDIC) and the National Bureau of Statistics. 


\section{Results}

The first question probed the general challenges faced by directors of Nigerian banks with regard to corporate governance. The results are shown in Table 4.

From the analysis, both the executive and non- executive directors were unanimous that the main challenge to good corporate governance in the Nigerian banking sector is that the shareholders are passive. Though not unanimous on other factors, they however ranked the following factors as important- overbearing influence of chairman or Managing director, ineffective board oversight function, poor risk management and insider related credits as well as self service practices among directors. Others are ignorance of and non-compliance with regulations and succumbing to pressure from other stakeholders. The Non-EDs and EDs are unanimous that the inability of management to respond to changing business circumstances posed the least challenge to corporate governance.

The post consolidation exercise in the banking sector posed fresh challenges to corporate governance in the banking sector. The second question sought to identify such challenges. The results are presented in table 5 .

The analysis in Table 5 indicates that the Non-EDs and EDs are unanimous on three out of the sixteen post consolidation challenges identified. The challenges which are ranked first, second and third respectively are: insider related lending, technical incompetence of most board members and ineffective board/statutory audit committee. Other important challenges which they identified as important but over which they differ in terms of ranking, include lack of transparency in disclosure of information as well as concealment of off balance sheet transactions and resurgence of high level malpractices. The Non-EDs and EDs are also unanimous that the disposal of surplus assets poses the least challenge.

The third question sought to identify the factors that could strengthen corporate governance in the banking sector. The results are presented in Table 6 .

The analysis in Table 6 indicates that the Non-EDs and EDs are unanimous that effective and efficient audit committee of the board is key to achieving good corporate governance in the banking sector. Other factors which they indicate are important but in respect of which they differ in terms of ranking include-effective oversight of executive management by the board, presence of knowledgeable directors in business financial matters and defined tenure for CEOs. The Non-EDs also support more non-executive director on the board and the EDs consider that the head of internal audit should report to the board audit committee. The Non-EDS and EDs are also unanimous that the remuneration of the EDS should not be determined by the EDs.

\section{Discussion}

The shareholders in the banking sector are regarded as passive, not out of choice or for want of laws and regulations. The Companies and Allied Matters Act, CAP C20 LFN (2004) in Section 79 (81) provides that "every member shall have a right to attend any general meeting of the company and to speak and vote on any resolution before the meeting." Though this provision subsists, most shareholders are not able to participate in such meetings due to cost and distance of venue of such meetings which are deliberately scheduled at Abuja and Lagos. This is in utter disregard of the provision under Part B, Section 9C of the Code of Corporate Governance in Nigeria 2003, which provides that "the venue of a general meeting of shareholders should be carefully chosen in such a way as to make it possible and affordable (in terms of distance and cost) for the majority of shareholders to attend and vote, and not to disenfranchise shareholders on account of choice of venue, which is unreasonable or impracticable to reach.

The other main challenges identified--overbearing influence of chairman or Managing director, ineffective board oversight function, poor risk management and insider related credits, self service practices among directors, ignorance of and non-compliance with regulations and succumbing to pressure from other stakeholders, arise also in defiance of the provisions of the Code of Corporate Governance. For instance, the Code provides that members of the board should be individuals with "upright personal characteristics and relevant core competences, preferably with a record of tangible achievement, knowledge on board matters, a sense of accountability, integrity, commitment to the task of corporate governance and institution building, while also having an entrepreneurial bias." However, the manner in which persons get to serve on the board of banks does not suggest that any meaningful steps are taken to ensure required quality.

According to Okpara, (2000), board members are picked from "the pool of high-profiled retired senior military officers and civil servants without expertise in basic finance and business operations." He further noted that "these set of never-do-well saboteurs sit atop the over populated board of directors (average 40-50 members) with the sole purpose to perpetuate corrupt practices particularly fixing the remunerations of senior executives which compromise corporate governance etiquette and decorum." This observation is further buttressed by Oyejide and Soyibo, (2001) and Quadri, (2010) who noted that, in the Nigerian context, board members (executive or non-executive) are handpicked, not 
independent and are not necessarily bound (legally or by default) to place higher value on shareholders interests nor protect the business interests, let alone the interests of stakeholders

The most undesirable corporate governance issue arising from the post consolidation era and over which the respondents were unanimous is insider-related lending. The monster called insider-related lending in Nigeria, Quadri (2010) noted, resulted in massive and prevalent frauds, mandatory retirement of CEOs of banks due to corrupt practices which was made possible by inefficient and rubber-stamped boards. These activities, he further noted, combined to signal the absence of or failure of existing corporate governance structure in Nigeria and concluded that the Company and Allied Matters Act (CAMA) enacted to regulate and balance the relationship among the board, shareholders and the management including other stakeholders, failed woefully due to inadequate enforcement capacity.

The respondents were also unanimous that ineffective board/statutory audit committee pose challenges in the post consolidation era. This is confirmed by earlier observations by Okike, (2007) and Bakare, (2007), who noted that the audit committees of Nigerian companies have been supposedly contributing to the corporate scandals by not performing their roles effectively. The reason for the situation is not far fetched. According to Owolabi and Ogbochie (2011), the audit committee is "usually not economically independent of management of the companies they serve and this contributes in no small measure to the poor quality of the report produced. In practice, management is also responsible for the appointment of the committee members and thus creating a situation that does not guarantee arm's length dealing or transparency." They further noted that most audit committees in Nigeria have no time to watch for details in financial reporting, nor to design and implement a strong internal control system to prevent poor reporting and lack the technical expertise to examine 'appropriate' accounting principles.

Similarly, Ogbechie and Koufopoulos (2007) found that most audit committees of publicly quoted companies in Nigeria have executive directors as members, which goes against global best practices that exclude executive directors from membership. For instance, in the 2007 financial year, the chairman of the audit committee of the Prestige Assurance Plc (a company quoted on the Nigerian Stock Exchange) was the Managing Director/CEO of the company.

The respondents are unanimous that effective and efficient audit committees are needed to bring sanity into the corporate governance of banks in Nigeria. If the audit committee is both active and independent, it may be able to deter fraudulent and misleading financial reporting through its relationships with the external auditor and the internal auditor. They also acknowledge that effective oversight of executive management by the board by knowledgeable directors in business financial matters would contribute to improve the state of corporate governance in Nigeria.

\section{Conclusion}

That the Nigerian banking sector has suffered from a lot of debilitating problems arising mainly from internal and external variables has been variously acknowledged. The problems have been accentuated by high level of unethical practices as revealed by the legion of fraudulent practices, which cut across all cadres of employees in the banks. Even though the various governments have attempted to address the situation through the enactment of laws and regulations, including codes of corporate governance, the situation remains unabated. The laws have certainly become inadequate in addressing the trend. While code of corporate governance is important, it is not on its own enough to achieve the objective of assuring quality and consistency of quality in the provision of professional services by directors. Values are critical in driving good corporate governance among directors as no codes/regulation can be truly effective unless it is accompanied by ethical behavior.

In order to achieve beneficial results the banks have to constantly ensure that ethical standards keep pace with changes in the banking sector. The banks should be seen to be approaching unethical practices from both judgmental and moralistic perspectives. As bankers, it would continue to be useful to reiterate that ethics are concerned with notions of rights and wrongs and good and bad against the background of accepted societal standards and expectations. The size of a bank like any other business is not an 'insurance' against failure. Thus the efficiency and effectiveness of the board, audit committee and management to create value for shareholders, customers and employees and make positive impacts on the economic growth within the context of ethical practice is imperative. So all corporate governance issues should be taken seriously by directors, managers and officers alike.

\section{Recommendation}

Although most of the issues identified by the respondents as strengths that could promote good corporate governance in banks are common knowledge and contained in the various codes, the study has shown that they differ in their potential and perceived effectiveness. It would therefore be necessary to direct attention to those that have the potential to address the corporate governance lapses in the Nigerian banking sector. In this regard, the following recommendations are made - 
(i) Shareholder activism should be legally required and encouraged. The level of such activism should be reported upon by the chairman in his statement and the auditors in their report.

(ii) The audit committee should be made up of credible persons and be responsible for hiring, firing and recommending the fees for non-executive directors and external auditors. Besides, executive directors should not be members of the audit committee.

(iii) There should be good training programmes that will keep the directors' skills up to date with their regulatory responsibilities.

(iv) The board should regularly obtain legal and professional advice regarding any changes in the legislation governing directors' responsibilities.

(v) The non-executive directors should not depend on the appointment to supplement income.

Though a number of recommendations have been made based on the results of this study, however, not much policy implication may be drawn from it due to the limitation of sample size. We therefore recommend that further studies should consider this limitation and increase the sample size.

\section{References}

Adedipe, A. (2005). Building and sustaining corporate performance and growth in the capital market. The Nigerian Stock Market Annual, 34-39.

Aikhorin, O. (1994). Bank fraud. Unpublished Masters, Seminar paper, University of Benin, Nigeria.

Al-Faki, M. (2007). Good Corporate Governance: Essentials for Leadership and Performance Excellence, [Online] available: http://sec.gov.ng/papersgovernances.htm

Bakare, O. M. (2007). 'The unethical practices of accountants and auditors and the compromising stance of professional bodies in the corporate world: evidence from corporate Nigeria', Accounting Forum, September, Vol. 31, No. 3, pp. 277 -303 .

Ball, Ian. (2004). Good Corporate Governance, IFAC Quarter Report.

Central Bank of Nigeria (CBN). (2006). Code of Corporate Governance for Banks in Nigeria Post Consolidation, [Online] available: http://www.cenbank.org/OUT/PUBLICATIONS/BSD/2006/CORPGOV-POSCO.

Kibanja, G. M. and Munene, J. C. (2009). A gender analysis of banks loan negotiations in Uganda. Journal of African Business, 10 (1), 105-119. http://dx.doi.org/10.1080/15228910802701544

Kolawole, Y. (2007). Banks Reckless Pursuit of Deposits still a concern - CBN, The Business Vanguard Monday $7^{\text {th }}$ May.

Krishnaswami, O. (2003). Methodology of research in social sciences. New Delhi. Himalay Publishing House.

Nigeria Deposit Insurance Corporation (NDIC). Annual Report and Statement of Accounts, various issues.

Nwankwo, G. O. (1991). Money and Capital Markets in Nigeria Today. Lagos: University of Lagos Press.

Ogbechie, C. and Koufopoulos, D. (2007). 'Corporate governance practices of publicly quoted companies in Nigeria', Int. Journal of Business Governance and Ethics, Vol. 3, No. 7, pp. 350-381. http://dx.doi.org/10.1504/IJBGE.2007.015206

Okechukwu, C. K. (2007). Corporate Governance in Banking and Other Financial Institutions; Laws and Issues and Ethics. Yaba: CIBN Press Ltd.

Okike, E. N. M. (2007). 'Corporate governance in Nigeria: the status quo', Corporate Governance, Vol. 15, No. 2, pp. 173 - 193. http://dx.doi.org/10.1111/j.1467-8683.2007.00553.x

Okike, N. (2004). Management of crisis: the response of the auditing profession in Nigeria to the challenges to its legitimacy. Accounting, Auditing \& Accountability Journal, $17(5)$ : 705-729. http://dx.doi.org/10.1108/09513570410567782

Oloshore, S. E. (1992). The Financial Sector in Africa: Overview and Reforms in economic Adjustment programmes. CBN Economic and Financial review, 2 (2), June.

Owolabi, A and Ogbechie, C. (2011). Audit committee reports and corporate governance in Nigeria. International Journal of Critical Accounting, 3 (2/3).

Oyejide, T. A. and Soyibo, A. (2001). Corporate Governance in Nigeria. Paper Presented at the Conference on Corporate Governance, Accra, Ghana, 29 - 30 January, 2001. 
Quadri, H. A. (2010). Conceptual Framework for Corporate Governance in Nigeria Challenges and Panaceas. PM World Today, 12 (9).

Shleifer, A. and Vishny, R. (1997). A Survey of Corporate Governance. Journal of Financial Economics, 52 (2), 737-83. Soludo C.C. (2004). Consolidating the Nigerian banking industry to meet the development challenges of the $21 \mathrm{st}$ century. Address at the Special Meeting of the Bankers Committee, Abuja, July 6.

Table 1. Summary of Bank credits granted owners and Directors of some selected banks in liquidation

\begin{tabular}{|l|l|l|l|l|}
\hline S/N & Banks (in Liquidation) & No of Directors involved & Amount (N) & $\%$ of Total Risk assets \\
\hline 1 & Alpha Merchant Bank Plc & 11 & $1,314,418,700.43$ & $33 \%$ \\
\hline 2 & United Commercial Bank Ltd & 5 & $741,755,808.86$ & $30 \%$ \\
\hline 3 & Financial Merchant Bank Ltd & 1 & $383,061,096.00$ & $100 \%$ \\
\hline 4 & Highland Bank of Nigeria Plc & 12 & $33,197,157.58$ & $38 \%$ \\
\hline 5 & Commercial Trust Bank Ltd & 1 & $247,749,719.10$ & $38 \%$ \\
\hline 6 & ABC Merchant Bank Ltd & 8 & $27,2981,634.00$ & $49 \%$ \\
\hline 7 & Royal Merchant Bank Ltd. & 7 & $646,940,182.23$ & $69 \%$ \\
\hline 8 & North-South Bank of Nigeria Ltd. & 13 & $240,668,637.62$ & $32 \%$ \\
\hline 9 & Abacus Merchant Bank Ltd. & 14 & $568,888,254.11$ & $47 \%$ \\
\hline 10 & Credit Bank Nig Ltd. & 6 & $379,934,611.47$ & $76 \%$ \\
\hline 11 & Prime Merchant Bank Ltd. & 1 & $539,292,310.00$ & $64 \%$ \\
\hline 12 & America Bank of Nig Ltd. & 7 & $149,854,896.00$ & $56 \%$ \\
\hline 13 & Century Merchant Bank Ltd. & 5 & $272,072,261.00$ & $32 \%$ \\
\hline 14 & Group Merchant Bank Ltd. & 13 & $595,836,077.20$ & $80 \%$ \\
\hline 15 & Commerce Bank Plc & 4 & $1,294,851,665.64$ & $52 \%$ \\
\hline 16 & Pinnacle Commercial Bank Ltd. & 10 & $298,766,751.76$ & $20 \%$ \\
\hline 17 & Republic Bank Ltd. & 1 & $161,375,466.00$ & $38 \%$ \\
\hline
\end{tabular}

Source: NDIC Annual Reports and Statement of Accounts, 2007

Table 2. Number of Fraud Cases and Banks' Staff

\begin{tabular}{|l|l|l|l|l|l|}
\hline Year & No of Fraud Cases & $\begin{array}{l}\text { Managers/ } \\
\text { Supervisors }\end{array}$ & $\begin{array}{l}\text { Officers / } \\
\text { Accountants }\end{array}$ & Clerks / Cahiers & Typists/others \\
\hline 1994 & 737 & 211 & 144 & 220 & 162 \\
\hline 1995 & 625 & 151 & 142 & 172 & 160 \\
\hline 1996 & 552 & 218 & 96 & 145 & 93 \\
\hline 1997 & 566 & 203 & 154 & 124 & 85 \\
\hline 1998 & 311 & 112 & 72 & 82 & 45 \\
\hline 1999 & 596 & 178 & 144 & 92 & 182 \\
\hline 2000 & 493 & 132 & 101 & 137 & 123 \\
\hline 2001 & 152 & 55 & 60 & 30 & 07 \\
\hline 2002 & 85 & 16 & 48 & 13 & 08 \\
\hline 2003 & 106 & 25 & 41 & 25 & 15 \\
\hline 2004 & 383 & 157 & 129 & 61 & 36 \\
\hline 2005 & 378 & 169 & 124 & 54 & 31 \\
\hline 2006 & 331 & 118 & 90 & 50 & 73 \\
\hline 2007 & 273 & 84 & 89 & 34 & 66 \\
\hline Total & 5588 & 1829 & 1434 & 1239 & 1086 \\
& $100 \%$ & $32.75 \%$ & $25.66 \%$ & $22.17 \%$ & $19.43 \%$ \\
\hline
\end{tabular}

Source: NDIC Annual Reports and Statement of Accounts, $1994-2007$

Note: The above table reports the number of fraud cases involving bank staff other than the directors. The details show that fraud takes place at all the levels in the banks as it involves both managers and non managers. This suggests a total breakdown of internal control measures as well as corporate governance mechanism. Though there is no discernible trend in the number of cases, it is however apparent that the number of cases is large. 
Table 3. Summary of Bank Fraud from All the States in Nigeria

\begin{tabular}{|l|l|l|l|l|l|l|}
\hline YEAR & $\begin{array}{l}\text { Number of } \\
\text { Cases } \\
\text { Reported }\end{array}$ & $\begin{array}{l}\text { Number of } \\
\text { Cases } \\
\text { Prosecuted }\end{array}$ & $\begin{array}{l}\text { Number of } \\
\text { Persons } \\
\text { Arrested }\end{array}$ & $\begin{array}{l}\text { Number of } \\
\text { Persons } \\
\text { Convicted }\end{array}$ & $\begin{array}{l}\text { Number of } \\
\text { Cases Under } \\
\text { Investigation }\end{array}$ & $\begin{array}{l}\text { Amount Involved } \\
\text { (N) }\end{array}$ \\
\hline 1996 & 82 & 39 & 154 & 18 & 34 & $6,239,519,190.00$ \\
\hline 1997 & 38 & 7 & 62 & 3 & 11 & $421,171,721.00$ \\
\hline 1998 & 16 & 4 & 0 & 1 & 15 & $5,527,449.10$ \\
\hline 1999 & 14 & 3 & 23 & 0 & 11 & $110,446,910.00$ \\
\hline 2000 & 16 & 3 & 18 & 0 & 13 & $403,111,849.00$ \\
\hline 2001 & 18 & 5 & 30 & 0 & 10 & $104,239,119.00$ \\
\hline 2002 & 16 & 3 & 18 & 0 & 13 & $413,118,181.00$ \\
\hline 2003 & 9 & 1 & 4 & 0 & 7 & $16,689,085.00$ \\
\hline 2004 & 2 & 0 & 2 & 0 & 1 & $567,000.00$ \\
\hline 2005 & 13 & 1 & 16 & 0 & 12 & $200,756,000.00$ \\
\hline 2006 & 7 & 1 & 15 & 0 & 6 & $721,313,506.00$ \\
\hline Total & 231 & 67 & 342 & 22 & 133 & $8,636,460,010.10$ \\
\hline
\end{tabular}

Source: National Bureau of Statistics, December, 2006 and 2007.

Table 4. General Challenges of Corporate Governance of Banks in Nigeria

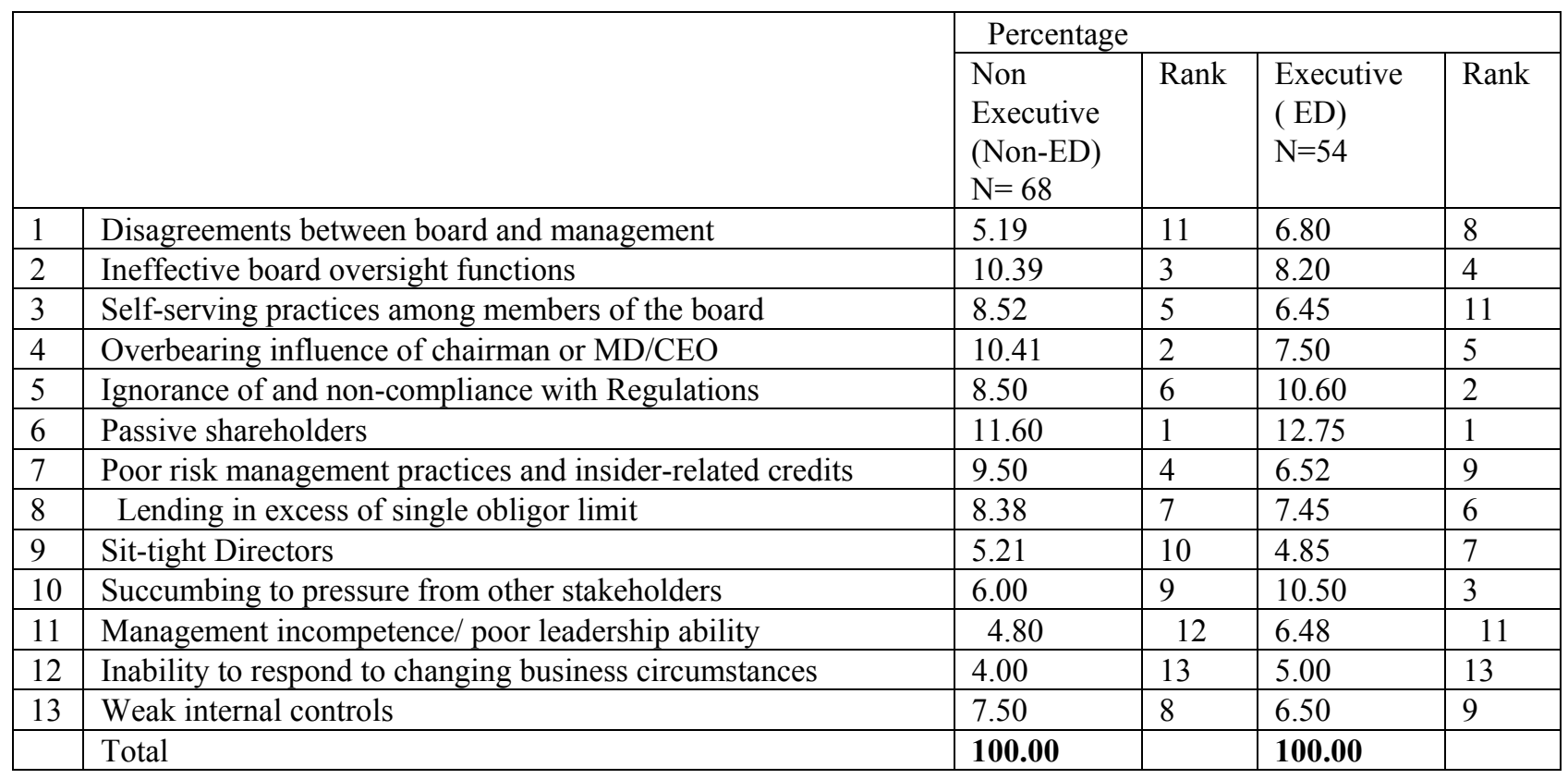


Table 5. Post Consolidation Challenges of Corporate Governance in Banks

\begin{tabular}{|l|l|l|l|l|l|}
\hline & \multicolumn{3}{|l|}{ Percentage } & \multicolumn{3}{l|}{$\begin{array}{l}\text { Non-Execu } \\
\text { tive } \\
\text { (Non-EDs) } \\
\mathrm{N}=68\end{array}$} & $\begin{array}{l}\text { Rank } \\
\text { (EDs) } \\
\text { N=54 }\end{array}$ & Rank \\
\hline 1 & Technical incompetence of most board members & 12.50 & 2 & 11.60 & 2 \\
\hline 2 & Relationships among directors & 3.50 & 12 & 4.80 & 10 \\
\hline 3 & Relationship between Management and Staff & 2.00 & 15 & 3.40 & 15 \\
\hline 4 & Increased levels of risks & 3.80 & 11 & 4.90 & 8 \\
\hline 5 & Ineffective integration of entities & 4.50 & 10 & 6.50 & 6 \\
\hline 6 & Poor Integration and development of information technology & 3.20 & 13 & 4.60 & 11 \\
\hline 7 & Inadequate management capacity & 5.60 & 8 & 5.00 & 9 \\
\hline 8 & Resurgence of high level malpractices & 6.00 & 7 & 8.40 & 4 \\
\hline 9 & Insider-related lending & 15.00 & 1 & 13.30 & 1 \\
\hline 10 & Rendition of false returns & 7.5 & 5 & 4.35 & 12 \\
\hline 11 & Concealment of off balance sheet commitments & 7.5 & 5 & 6.50 & 6 \\
\hline 12 & Ineffective board/statutory audit committee & 12.30 & 3 & 10.60 & 3 \\
\hline 13 & Inadequate operational and financial controls & 2.60 & 14 & 3.70 & 13 \\
\hline 14 & Absence of a robust risk management system & 4.90 & 9 & 3.65 & 14 \\
\hline 15 & Disposal of surplus assets & 1.50 & 16 & 2.00 & 16 \\
\hline 16 & Transparency and adequate disclosure of information & 7.60 & 4 & 6.70 & 5 \\
\hline & Total & & $\mathbf{1 0 0}$ & & $\mathbf{1 0 0}$ \\
\hline
\end{tabular}

Table 6. Strengths that Promote Good Corporate Governance

\begin{tabular}{|c|c|c|c|c|c|}
\hline & \multirow[b]{2}{*}{ Items } & \multicolumn{4}{|l|}{ Percentage } \\
\hline & & $\begin{array}{l}\text { Non-Executive } \\
\mathrm{N}=68\end{array}$ & Rank & $\begin{array}{l}\text { Executive } \\
\mathrm{N}=54\end{array}$ & Rank \\
\hline 1 & A proactive and committed board. & 6.00 & 9 & 6.00 & 11 \\
\hline 2 & Effective oversight of executive management by the board & 10.50 & 2 & 7.5 & 4 \\
\hline 3 & More non-executive directors than executive directors. & 7.50 & 5 & 6.3 & 10 \\
\hline 4 & Knowledgeable directors in business financial matters & 8.60 & 3 & 8.5 & 2 \\
\hline 5 & Effective and efficient Audit Committee of the Board & 10.70 & 1 & 12.60 & 1 \\
\hline 6 & Code of conduct/ethics for directors & 7.20 & 6 & 6.40 & 9 \\
\hline 7 & Absence of Executive duality & 4.50 & 13 & 6.70 & 6 \\
\hline 8 & Exclusion of family members from being chairman /CEO & 6.40 & 8 & 6.52 & 8 \\
\hline 19 & Regular training and education of board members & 5.00 & 12 & 6.60 & 7 \\
\hline 10 & Latitude to hire independent consultants to advise directors & 5.80 & 10 & 5.40 & 13 \\
\hline 11 & $\begin{array}{l}\text { Determination of remuneration of executive directors by } \\
\text { Non-executive directors }\end{array}$ & 2.40 & 15 & 1.5 & 15 \\
\hline 12 & $\begin{array}{l}\text { Limit Non-executive directors' remuneration to sitting } \\
\text { allowances/ fees/reimbursable travel and hotel expenses. }\end{array}$ & 4.30 & 14 & 5.00 & 14 \\
\hline 13 & Defined tenure for Non-executive directors & 7.00 & 7 & 6.00 & 11 \\
\hline 14 & Defined tenure for CEO directors & 8.50 & 4 & 6.80 & 5 \\
\hline 15 & $\begin{array}{l}\text { Head of internal audit to report directly to the board audit } \\
\text { committee }\end{array}$ & 5.60 & 11 & 8.00 & 3 \\
\hline
\end{tabular}

